\section{Sustaining Soil Quality in Intensively Managed High Tunnel Vegetable Production Systems: A Role for Green Manures and Chicken Litter}

\author{
Matt A. Rudisill and Bruce P. Bordelon \\ Department of Horticulture and Landscape Architecture, Purdue University, \\ 625 Agriculture Mall Drive, West Lafayette, IN 47907
}

\author{
Ronald F. Turco \\ Department of Agronomy, Purdue University, 915 W. State Street, West \\ Lafayette, IN 47907
}

\author{
Lori A. Hoagland ${ }^{1}$ \\ Department of Horticulture and Landscape Architecture, Purdue University, \\ 625 Agriculture Mall Drive, West Lafayette, IN 47907
}

Additional index words. hairy vetch, alfalfa meal, urea, chard, sweet pepper

\begin{abstract}
Use of high tunnel crop production is expected to increase to meet the growing demand for locally produced fresh market vegetables. These structures have the potential to offer many production benefits; however, managing soil quality in these structures is challenging and work in the area is limited. In this 3-year study, we compared the impacts of organic and inorganic fertility amendments on soil quality, nutrient availability, and the productivity of chard (Beta vulgaris L.) and sweet peppers (Capsicum annuum L.) produced in high tunnel and open field systems. Fertility amendments included a green manure treatment [hairy vetch (Vicia villosa Roth) and dehydrated alfalfa meal], partially composted and pelletized chicken litter, urea, and an unfertilized control. Chard was grown in 2011, and peppers were grown in 2012 and 2013. Soil nutrients, microbial activity, active carbon, $\mathbf{p H}$, electrical conductivity (EC), total soil organic matter, and yield were quantified. Chard yield was lower in the high tunnel compared with the open field in 2011, but pepper yield was greater in the high tunnel in 2012 and 2013. Productivity of chard was lower in the green manure compared with urea in 2011 across high tunnel and open field production systems, but no difference in pepper yield was observed between plants receiving fertility inputs in either 2012 or 2013. Repeated application of green manure and chicken litter resulted in soils with increased microbial activity and active carbon, but the green manure was the only treatment successful at accruing carbon in the high tunnel over time. High tunnel production resulted in greater EC compared with the open field, but levels were not considered inhibitory for chard or peppers. High tunnels can increase vegetable crop productivity in the midwest United States, and organic fertility amendments can improve soil quality as measured by soil microbial activity and active carbon in high tunnel and open field production systems.
\end{abstract}

Demand for fresh, locally sourced vegetables that are marketed directly to consumers is increasing across the United States (Timmons and Wang, 2010). One major trend among growers targeting these markets is the use of high tunnels to extend the growing season for increased crop productivity. High

Received for publication 16 Sept. 2014. Accepted for publication 18 Nov. 2014.

This work was supported by Purdue Agriculture Research Programs.

We thank Longjie Cheng and the Purdue Statistical Consulting Service for their assistance with statistical analyses. We also thank Nate Linder, Tristand Tucker, and Jay Young for assistance and guidance in plot management.

${ }^{1}$ To whom reprint requests should be addressed; e-mail lhoaglan@purdue.edu.
10,000 high tunnels since 2010 (G. Gilbert, personal communication), the best approaches to meeting these challenges is a critical question.

Soil quality is broadly defined as the ability of a soil to function in terms of sustaining plant productivity and moderating water and air quality, all while allowing for improvement in human health and habitation (USDA, 2014). Managing soil quality is difficult in intensively managed vegetable systems where regular tillage and substantial inputs are required to attain a desired level of crop productivity. Managing soil quality is likely to be even more challenging for vegetable growers using high tunnel structures as a result of longer, more intensive cultivation and modification of the soil system. As the use of these structures continues to increase, there is a critical need for research that will identify management practices that maintain or improve soil quality within these systems.

Organic fertility amendments have potential to improve soil quality while meeting nutrient needs in high tunnel systems. However, timing nutrient availability with periods of critical nutrient uptake with organic amendments can be difficult because the amendments must mineralize before they are available for plant uptake. Animal manures are commonly applied in high tunnel production systems and they have previously been shown to meet crop nutrient requirements (Knewtson et al., 2010a, 2010b). Amending soil with animal manures can benefit the soil system by inputting carbon (C) and organic nutrients, although repeated use can result in phosphorus $(\mathrm{P})$ accumulation because plants need more nitrogen $(\mathrm{N})$ relative to $\mathrm{P}$, and $\mathrm{P}$ accumulation can lead to negative environmental impacts (Edmeades, 2003). Furthermore, soluble salts have been shown to accumulate with prolonged use of animal manures (Yao et al., 2007). Excessive levels of soluble salts can negatively impact crop productivity (Maas and Hoffman, 1977). Accumulation of salts is of particular concern in high tunnels, where decreased exposure to rainfall and higher temperatures prevents leaching and increases evapotranspiration.

One alternative strategy to meet fertility needs and improve soil quality in high tunnels without the negative soil quality impacts that could result from animal manures is the use of green manures. Green manure fertility sources include cover crops that are tilled under before seeding or transplanting or the incorporation of dehydrated plant materials recovered at another location. Legumes (e.g., hairy vetch) are a popular choice as a result of their ability to fix atmospheric $\mathrm{N}$ and their narrow C-to-N ratio, which results in rapid mineralization and release of plant-available nutrients for subsequent crops. The benefits of green manures on soil and water quality are well established in exposed agricultural settings (Snapp et al., 2005). For example, incorporating legumes as green manure maintains nutrient pools with longer mean residence times, thus reducing nutrient loss through leaching (Komatsuzaki and Ohta, 2007; Snapp et al., 2005). These C-rich amendments can 
also replenish labile $\mathrm{C}$ pools that aid in the biochemical conversion of key plant nutrients (Drinkwater and Snapp, 2007). However, although green manure amendments have been tested for their impacts on crop productivity in high tunnels (Araki et al., 2009; O'Connell et al., 2012), their impact on soil quality has not been conclusively demonstrated.

The goal of this study was to determine how soil quality and vegetable productivity are impacted by organic and inorganic fertility amendments in high tunnel and open field production systems. We predicted that animal and green manure amendments could meet crop needs and increase soil quality relative to an inorganic fertility treatment and an untreated control, although green manures may not have some of the potential negative side effects that animal manures can have in high tunnel systems. This trial was conducted side by side in a high tunnel and open field setting to understand how the production systems alter $\mathrm{N}$ availability and influence the potential soil quality benefits of these amendments. The experiment was conducted over 3 years and quantified the impacts of repeated application of fertility amendments on soil nutrients, indicators of soil quality, and vegetable crop yield.

\section{Materials and Methods}

Site description and soil treatments. Field trials were conducted at the Meigs Horticulture Research Farm (lat. $40^{\circ} 17^{\prime} 21^{\prime \prime} \mathrm{N}$, long. $86^{\circ} 53^{\prime} 02^{\prime \prime} \mathrm{W}$ ), a subsection of Throckmorton Purdue Agriculture Center, located in Tippecanoe County, IN. The mean annual precipitation at this site is $1008 \mathrm{~mm}$, and summer temperatures typically range from 21.1 to $26.7^{\circ} \mathrm{C}$ with mean maximum temperatures reaching $29.5^{\circ} \mathrm{C}$. Soil at this site is from the Drummer soil series (fine-silty, mixed, mesic Typic Endoaquoll) that typically contains $\approx 3.2 \%$ organic matter and has a neutral $\mathrm{pH}$. Previous management history at this site (200209) consisted of a conventional corn/soybean [Zea mays L./Glycine max (L.) Merr.] rotation with variable rates of fertilizer depending on the crop that was grown. In 2010, high tunnels $(14.6 \times 7.9 \times 3.7 \mathrm{~m}$, Quonset-frame, 6-mil single-layer polyethylene) were constructed in an east-to-west orientation at this site, and adjacent open field settings of the same size were left uncovered for comparison trials. Our study was conducted in one of the high tunnel and open field pairs from Spring 2011 to Fall 2013.

Soil fertility amendments used in this trial included: 1) green manure consisting of fallseeded (broadcast at $33.6 \mathrm{~kg} \cdot \mathrm{ha}^{-1}$ ) hairy vetch (Vicia villosa; Johnny's Selected Seeds, Albion, ME) supplemented with dehydrated alfalfa meal $[(3.0 \mathrm{~N}-0.2 \mathrm{P}-0.8 \mathrm{~K})$; Fertrell, Bainbridge, PA]; 2) animal manure (partially composted and dehydrated chicken litter, $3.0 \mathrm{~N}-0.9 \mathrm{P}-2.5 \mathrm{~K}$; Fertrell), 3) urea $(46 \mathrm{~N}-$ OP-0K); and 4) unfertilized control. The animal manure and green manure were supplemented with Phostrell (0N-2.6P-0K; Fertrell) and sulfate of potash $(0 \mathrm{~N}-0 \mathrm{P}-43.2 \mathrm{~K}$; Fertrell) and urea was supplemented with triple superphosphate $(0 \mathrm{~N}-20.1 \mathrm{P}-0 \mathrm{~K})$ and potassium chloride $(\mathrm{KCl} ; 0 \mathrm{~N}-0 \mathrm{P}-49.8 \mathrm{~K})$ to provide additional $\mathrm{P}$ and potassium $(\mathrm{K})$ as needed to meet recommended crop nutrient needs. The annual fertility contribution of the hairy vetch green manure crop was estimated by calculating the amount of dry biomass and determining the $\mathrm{N}$ content of subsampled tissue by combustion analysis. All amendments were incorporated in the spring of each growing season to a depth of $15.0 \mathrm{~cm}$.

Experimental design. Field plots were established in Spring 2011 using a randomized complete block design with four replicates in the high tunnel and adjacent open field settings. Experimental subplots measured $5.5 \mathrm{~m}^{2}$. Amendments were applied at a rate of $112 \mathrm{~kg} \mathrm{~N} / \mathrm{ha}, 49.3 \mathrm{~kg} \mathrm{P} / \mathrm{ha}$, and $83 \mathrm{~kg}$ $\mathrm{K} /$ ha in 2011 based on initial soil nutrient analysis and nutrient requirements for swiss chard (Maynard and Hochmuth, 1997), and the green manure treatment consisted solely of dehydrated alfalfa meal. Swiss chard (Beta vulgaris 'Fordhook Giant'; Johnny's Selected Seeds) was direct-seeded at a rate of 30 seeds $/ \mathrm{m}$ with $60-\mathrm{cm}$ between-row spacing in both the high tunnel and open field on 28 Apr. 2011, and drip tape was placed every $0.5 \mathrm{~m}$. Chard plants were thinned to a $30-\mathrm{cm}$ in-row spacing resulting in 14 plants per plot (2.6 plants $\left./ \mathrm{m}^{2}\right)$. Amendment application rates were increased in subsequent growing seasons to compensate for low yields observed in chard plants in 2011 and greater nutritional needs for sweet peppers (Maynard and Hochmuth, 1997) grown in 2012 and 2013. Rates were adjusted to $168 \mathrm{~kg} \mathrm{~N} / \mathrm{ha}$ for urea, $196 \mathrm{~kg} \mathrm{~N} / \mathrm{ha}$ for animal manure, and $336 \mathrm{~kg} \mathrm{~N} /$ ha for green manure based on initial soil nutrient analysis and estimated $\mathrm{N}$ availability from broiler litter (Bary et al., 2000) and legume biomass (Sarrantonio, 1994). Additionally, P and K application rates were adjusted to $98.6 \mathrm{~kg} \mathrm{P} / \mathrm{ha}$ and $186 \mathrm{~kg} \mathrm{~K} / \mathrm{ha}$. Sweet pepper (Capsicum annuum 'California Wonder'; Burpee Seeds, Warminster, PA) transplants were started in the greenhouse in mid-March each growing season. Raised beds with a height of $30 \mathrm{~cm}$ and width of $60 \mathrm{~cm}$ were constructed in each subplot. Drip tape was placed in each raised bed and covered with black plastic mulch to control weeds within and between rows. In both settings, peppers were transplanted with a $45-\mathrm{cm}$ in-row and $60-\mathrm{cm}$ between-row spacing for a total of 12 plants per plot (2.2 plants/ $\mathrm{m}^{2}$ ). In 2012, peppers were planted on 3 May and 23 May in the high tunnel and open field, respectively, which reflected standard grower practice for planting earlier in high tunnels relative to open field settings. In 2013, peppers were planted on 5 June and 7 June in the high tunnel and open field, respectively, to determine the potential benefits of the high tunnel on crop productivity beyond the earlier planting date that can be achieved. High tunnel irrigation rates were set to supply $\approx 2 \mathrm{~L}$ of tap water per plant per day. Irrigation was applied in the open field setting as needed in the absence of rainfall events. Soil moisture content was measured periodically throughout each growing season at a depth of $7.5 \mathrm{~cm}$ using a portable soil moisture probe (FieldScout TDR 300; Spectrum Technologies, Inc., Plainfield, IL), particularly during times of intense heat, to ensure crop water requirements were being met. Weeds between rows and at the base of each plant were pulled by hand as needed. Insects and plant pathogens did not reach critical thresholds in our trials, and pesticides were not applied at any time during the study. Air temperatures were monitored at $1.5 \mathrm{~m}$ above the soil surface at the center of each production system throughout each growing season in both the high tunnel and open field settings using data loggers (WatchDog Series 125; Spectrum Technologies, Inc.).

Soil sampling and analysis. Before plot establishment, 10 baseline soil samples were randomly collected from each block in Apr. 2010 using a $2.0-\mathrm{cm}$ diameter soil probe to a depth of $30 \mathrm{~cm}$, pooled, and homogenized to determine baseline fertility and soil quality parameters. Subsequent soil sampling was conducted in each treatment plot at 63 to $70 \mathrm{~d}$ postamendment incorporation (midseason) and at the conclusion of each season (end of season) as described previously. Midseason soil sampling occurred on 30 June 2011, 6 July 2012, and 6 Aug. 2013 in the high tunnel and on 30 June 2011, 1 Aug. 2012, and 6 Aug. 2013 in the open field. End-of-season soil sampling occurred on 29 Sept. 2011, 10 Oct. 2012, and 11 Oct. 2013 in the high tunnel and on 29 Sept. 2011, 9 Oct. 2012, and 11 Oct. 2013 in the open field. All samples were placed in polyethylene bags and stored on ice for transport to the laboratory. Aliquots of each soil sample were either stored at $4.0^{\circ} \mathrm{C}$ or air-dried and sieved $(2.0 \mathrm{~mm})$ before analysis.

Soil pH and EC of all midseason samples were determined by a soil suspension method using a 1:2 soil-to-deionized water ratio (Dellavalle, 1992; Kalra, 1995). Measurements were taken using a multimeter (sensION+ mm150; Hach Company, Loveland, CO). Ammonium$\left(\mathrm{NH}_{4}{ }^{+}-\mathrm{N}\right)$ and nitrate/nitrite- $\left(\mathrm{NO}_{\mathrm{x}}-\mathrm{N}\right) \mathrm{N}$ concentration of all midseason and end-of-season samples were determined colorimetrically (AQ2 Discrete Analyzer; SEAL Analytical, Mequon, WI) after $\mathrm{KCl}$ extraction. Concentrations of $\mathrm{NH}_{4}{ }^{+}-\mathrm{N}$ and $\mathrm{NO}_{\mathrm{x}}-\mathrm{N}$ were combined and expressed as mineral $\mathrm{N}$. Total nutrient analysis of 2013 end-of-season samples was determined by Midwest Laboratories (Omaha, NE) according to common soil analysis methods for this region (Brown, 1998). Organic matter was determined using loss of weight on ignition; available $\mathrm{P}$ was extracted as Weak Bray (readily available P) and Strong Bray (potentially available P) and analyzed colorimetrically; exchangeable $\mathrm{K}$, calcium $(\mathrm{Ca})$, and magnesium $(\mathrm{Mg})$ were extracted with neutral ammonium acetate $(1 \mathrm{~N})$ and quantified by inductively coupled argon plasma-mass spectrometry detection; and base saturation and cation exchange capacity $\left[\mathrm{mmol}_{(+)} \cdot \mathrm{kg}^{-1}\right]$ were estimated from the results of exchangeable minerals (Brown, 1998).

Microbial activity was estimated using the hydrolysis of fluorescein diacetate (FDA) in soil 
slurries on all midseason soils using a method optimized for soil (Green et al., 2006). Active $\mathrm{C}$ was quantified using the permanganate oxidizable carbon (POXC) technique (Weil et al., 2003) on all midseason soil samples. Reacted samples and standards were measured on a plate reader (BioTek Epoch; BioTek, Winooski, VT) at $490 \mathrm{~nm}$ and $550 \mathrm{~nm}$ for FDA and POXC, respectively.

Plant measurements and yield. Relative chlorophyll content was estimated using a portable chlorophyll meter (SPAD 502; Minolta Corporation, Ramsey, NJ) every 4 weeks during the growing season. Three readings of newly developed leaves from each plant were averaged, and four plants per treatment plot were measured. In 2011, chard was harvested three times by cutting all leaves $5.0 \mathrm{~cm}$ above the growing point beginning on 12 June 2011 and ceasing on 16 Sept. 2011 for both the open field and high tunnel. In 2012 and 2013, pepper fruit were harvested every 3 to 4 weeks when all treatment plots had mature fruit. All mature fruit at the green or red stage were removed, and immature fruit were left on the plant. Harvests in the high tunnel began on 12 July 2012 and 6 Aug. 2013 and ceased on 26 Sept. 2012 (four harvests) and 2 Oct. 2013 (four harvests). Harvests in the open field began on 31 July 2012 and 8 Aug. 2013 and ceased on 5 Oct. 2012 (three harvests) and 2 Oct. 2013 (four harvests). Peppers were separated into marketable and unmarketable categories. Fruit with blossom end rot incidence, sunscald, and severe physiological deformities were considered unmarketable. Marketable fruits were graded based on USDA standards (USDA, 2005). All yield measurements were adjusted to a per-plant basis at the time of each harvest to account for destructive plant sampling and plant loss throughout the growing season. Data for each harvest were combined and reported as total yield across the season.

Statistical analysis. Statistical analyses were carried out using SAS 9.2 (SAS Institute, Cary, NC). Two-way analysis of variance (ANOVA) (proc GLIMMIX) was used to determine differences among production system, fertility treatment, and their interaction. A weighted two-way ANOVA model was used when the homogeneity of variance was significant $(P \leq$ $0.05)$ according to Levene's test. Changes in soil quality indicators over time were assessed using linear regression (proc REG). Differences were determined as significant at the $P \leq 0.05$ level, unless otherwise stated. All multiple comparisons were made using Tukey adjusted least-square means when the ANOVA F-test was statistically significant $(P \leq 0.05)$.

\section{Results}

Yield and fruit grades. In 2011, chard yield was greater in the open field than the high tunnel (Table 1), and yield was greater in the urea treatment than the green manure. In 2012 and 2013, marketable pepper yield was greater in the high tunnel than in the open field, whereas unmarketable yield was lower in the high tunnel in both seasons. Fertility treatments did not impact the yield of marketable fruit in 2012, but did impact unmarketable yield, where the animal manure was greater than the control. In 2013, marketable yield was greater in plants receiving fertility inputs than the control, and the yield of unmarketable fruit was lower in the green manure compared with urea and animal manure treatments.

Pepper fruit grade was also impacted by production system and fertility treatments. Across both years, peppers grown in the high tunnel produced greater numbers of all fruit grades compared with the open field (Table 2). In 2012, plants receiving fertility inputs produced a greater number of U.S. Fancy fruit compared with the control. Differences between fertility treatments were observed among all measured fruit grades in 2013. On average, plants receiving fertility inputs produced greater numbers of U.S. Fancy and U.S. No. 1 than the control with the exception of U.S. No. 2, where only the animal manure was greater than the control.

Mineral nitrogen and leaf SPAD. Midseason mineral $\mathrm{N}$ was impacted by production system in all growing seasons. In 2011 and 2013, mineral $\mathrm{N}$ was greater in the open field compared with the high tunnel (Table $3)$. In contrast, in 2012, greater amounts of mineral $\mathrm{N}$ were observed in the high tunnel. Fertility treatments only had a significant

Table 1. Mean yield of chard and peppers from four fertility treatments in high tunnel and open field systems over three growing seasons (2011-13).

\begin{tabular}{|c|c|c|c|c|c|c|}
\hline \multirow[b]{3}{*}{ Treatment } & \multirow{3}{*}{\multicolumn{2}{|c|}{ 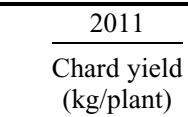 }} & \multicolumn{2}{|c|}{2012} & \multicolumn{2}{|c|}{2013} \\
\hline & & & \multicolumn{4}{|c|}{ Pepper yield $\overline{(\mathrm{kg} / \mathrm{plant})}$} \\
\hline & & & $\overline{\text { Marketable }}$ & Unmarketable $^{\mathrm{z}}$ & Marketable & Unmarketable \\
\hline \multicolumn{7}{|l|}{$\overline{\text { Production system }}$} \\
\hline High tunnel & & $0.58 \mathrm{~b}^{\mathrm{y}}$ & $1.27 \mathrm{a}$ & $0.55 \mathrm{~b}$ & $1.68 \mathrm{a}$ & $0.22 \mathrm{~b}$ \\
\hline Open field & & $0.77 \mathrm{a}$ & $0.35 \mathrm{~b}$ & $0.84 \mathrm{a}$ & $1.05 \mathrm{~b}$ & $0.30 \mathrm{a}$ \\
\hline \multicolumn{7}{|l|}{ Fertility treatment } \\
\hline Control & & $0.58 \mathrm{ab}$ & $0.60 \mathrm{a}$ & $0.41 \mathrm{~b}$ & $0.72 \mathrm{~b}$ & $0.25 \mathrm{ab}$ \\
\hline Urea & & $0.86 \mathrm{a}$ & $0.93 \mathrm{a}$ & $0.75 \mathrm{ab}$ & $1.61 \mathrm{a}$ & $0.26 \mathrm{~b}$ \\
\hline Chicken manure & & $0.81 \mathrm{ab}$ & $0.85 \mathrm{a}$ & $0.87 \mathrm{a}$ & $1.66 \mathrm{a}$ & $0.34 \mathrm{~b}$ \\
\hline Green manure & & $0.46 \mathrm{~b}$ & $0.86 \mathrm{a}$ & $0.74 \mathrm{ab}$ & $1.47 \mathrm{a}$ & $0.19 \mathrm{a}$ \\
\hline Factor & $\mathrm{df}$ & & & $P>\mathrm{F}$ & & \\
\hline Production system (PS) & 1 & 0.0464 & $<0.0001$ & $<0.0001$ & $<0.0001$ & 0.0068 \\
\hline Fertility treatment (FT) & 3 & 0.0140 & 0.2419 & 0.0077 & $<0.0001$ & 0.0022 \\
\hline $\mathrm{PS} \times \mathrm{FT}$ & 3 & 0.9437 & 0.9465 & 0.3385 & 0.2753 & 0.3533 \\
\hline
\end{tabular}

${ }^{2}$ Unmarketable pepper yield.

${ }^{y}$ Values within a column are not significantly different from each other if marked with the same letter as determined by Tukey's honestly significant difference test $(P \leq 0.05)$.

Table 2. Mean USDA fruit grades of peppers from four fertility treatments in high tunnel and open field systems in 2012 and 2013.

\begin{tabular}{|c|c|c|c|c|c|c|c|}
\hline \multirow{3}{*}{ Treatment } & & \multicolumn{3}{|c|}{2012} & \multicolumn{3}{|c|}{2013} \\
\hline & & \multicolumn{3}{|c|}{ No./plant } & \multicolumn{3}{|c|}{ No./plant } \\
\hline & & Fancy & No. 1 & No. 2 & Fancy & No. 1 & No. 2 \\
\hline \multicolumn{8}{|l|}{ Production system } \\
\hline High tunnel & & $1.31 \mathrm{a}^{\mathrm{z}}$ & $3.45 \mathrm{a}$ & $6.66 \mathrm{a}$ & $2.07 \mathrm{a}$ & $4.97 \mathrm{a}$ & $7.53 \mathrm{a}$ \\
\hline Open field & & $0.16 \mathrm{~b}$ & $0.76 \mathrm{~b}$ & $2.99 \mathrm{~b}$ & $1.08 \mathrm{~b}$ & $3.01 \mathrm{~b}$ & $5.77 \mathrm{~b}$ \\
\hline \multicolumn{8}{|l|}{ Fertility treatment } \\
\hline Control & & $0.16 \mathrm{~b}$ & $1.56 \mathrm{a}$ & $4.62 \mathrm{a}$ & $0.32 \mathrm{~b}$ & $2.26 \mathrm{~b}$ & $5.12 \mathrm{~b}$ \\
\hline Urea & & $0.74 \mathrm{a}$ & $2.47 \mathrm{a}$ & $5.11 \mathrm{a}$ & $2.10 \mathrm{a}$ & $4.65 \mathrm{a}$ & $7.11 \mathrm{ab}$ \\
\hline Chicken manure & & $0.85 \mathrm{a}$ & $2.15 \mathrm{a}$ & $5.05 \mathrm{a}$ & $2.01 \mathrm{a}$ & $4.93 \mathrm{a}$ & $7.51 \mathrm{a}$ \\
\hline Green manure & & $1.20 \mathrm{a}$ & $2.23 \mathrm{a}$ & $4.53 \mathrm{a}$ & $1.88 \mathrm{a}$ & $4.12 \mathrm{a}$ & $6.91 \mathrm{ab}$ \\
\hline Factor & $\mathrm{df}$ & \multicolumn{6}{|c|}{$P>\mathrm{F}$} \\
\hline Production system (PS) & 1 & 0.0001 & $<0.0001$ & $<0.0001$ & 0.0001 & $<0.0001$ & 0.0353 \\
\hline Fertility treatment (FT) & 3 & 0.0141 & 0.4243 & 0.8884 & $<0.0001$ & 0.0001 & 0.0051 \\
\hline $\mathrm{PS} \times \mathrm{FT}$ & 3 & 0.6261 & 0.7910 & 0.3957 & 0.2010 & 0.4916 & 0.5629 \\
\hline
\end{tabular}

${ }^{\mathrm{z}}$ Values within a column are not significantly different from each other if marked with the same letter as determined by Tukey's honestly significant difference test $(P \leq 0.05)$. 
Relative leaf chlorophyll abundance as estimated by a SPAD meter was not significantly different between plants receiving fertility inputs at all sampling points during each growing season in either the high tunnel or open field system (data not shown).

Soil quality. Soil microbial activity as estimated by FDA hydrolysis was not significantly different between production systems until 2013 when the high tunnel had a greater enzyme level than the open field (Table 4). The impact of fertility treatments on microbial activity was also not significantly different until 2013 when the soils receiving animal manure and green manure inputs had greater FDA hydrolysis than the urea and control treatments. Regression analysis of microbial activity over the course of the experiment indicated that animal manure and green manure treatments supported enhanced microbial activity in the high tunnel over time as shown in Figure 1. In contrast, a significant decline in microbial activity was observed in the control in the open field.

Active soil C, estimated by POXC, was significantly impacted by production system in 2011, where the high tunnel had a greater amount of POXC than the open field. In contrast, fertility treatments impacted active $\mathrm{C}$ in all growing seasons (2011-13). In 2011, soils receiving animal manure inputs were greater than the control, whereas in 2012, both animal manure and green manure treatments had greater amounts of POXC than urea and control treatments (Table 4). In 2013, the green manure treatment resulted in greater POXC when compared with urea and control treatments, whereas the animal manure was only greater than the control. A significant production system $\times$ fertility treatment interaction on POXC was observed in 2013, suggesting that fertility treatments impact active $\mathrm{C}$ differently between production systems. This interaction was largely driven by differences in the control between the two systems with greater levels of active $\mathrm{C}$ in the open field relative to the high tunnel system (OF, $509.1 \mathrm{mg} \mathrm{POXC} / \mathrm{kg}$ soil; HT, $382.8 \mathrm{mg} \mathrm{POXC} / \mathrm{kg}$ soil; $P=0.0062$ ). Regression trends in POXC over the course of the experiment revealed that the green manure treatment accrued active $\mathrm{C}$ over time in both the high tunnel and open field as shown in Figure 2, whereas a significant increase in POXC was also observed in the urea treatment, but only in the open field.

Table 3. Mean total mineral nitrogen $\left(\mathrm{NO}_{\mathrm{x}}-\mathrm{N}+\mathrm{NH}_{4}-\mathrm{N}\right)$ from midseason (Mid) and end-of-season (End) soil ( 0 - to $30-\mathrm{cm}$ depth) from four fertility treatments in high tunnel and open field systems over three growing seasons (2011-13).

\begin{tabular}{|c|c|c|c|c|c|c|c|}
\hline \multirow[b]{4}{*}{ Treatment } & & \multicolumn{6}{|c|}{ Total mineral $\mathrm{N}$} \\
\hline & & \multicolumn{6}{|c|}{ (mg N/kg soil) } \\
\hline & & \multicolumn{2}{|c|}{2011} & \multicolumn{2}{|c|}{2012} & \multicolumn{2}{|c|}{2013} \\
\hline & & Mid & End & Mid & End & Mid & End \\
\hline \multicolumn{8}{|l|}{ Production system } \\
\hline High tunnel & & $9.37 \mathrm{~b}^{\mathrm{z}}$ & $8.39 \mathrm{~b}$ & $18.5 \mathrm{a}$ & $11.0 \mathrm{a}$ & $7.32 \mathrm{~b}$ & $8.44 \mathrm{a}$ \\
\hline Open field & & $17.1 \mathrm{a}$ & $13.1 \mathrm{a}$ & $13.1 \mathrm{~b}$ & $12.1 \mathrm{a}$ & $11.9 \mathrm{a}$ & $6.51 \mathrm{~b}$ \\
\hline \multicolumn{8}{|l|}{ Fertility treatment } \\
\hline Control & & $9.44 \mathrm{~b}$ & $9.69 \mathrm{a}$ & $11.4 \mathrm{a}$ & $10.4 \mathrm{~b}$ & $7.63 \mathrm{a}$ & $6.33 \mathrm{a}$ \\
\hline Urea & & $14.8 \mathrm{a}$ & $13.9 \mathrm{a}$ & $15.9 \mathrm{a}$ & $11.6 \mathrm{ab}$ & $9.51 \mathrm{a}$ & $7.74 \mathrm{a}$ \\
\hline Chicken manure & & $15.8 \mathrm{a}$ & $8.83 \mathrm{a}$ & $18.9 \mathrm{a}$ & $11.1 \mathrm{ab}$ & $10.3 \mathrm{a}$ & $7.73 \mathrm{a}$ \\
\hline Green manure & & $13.0 \mathrm{ab}$ & $10.6 \mathrm{a}$ & $17.0 \mathrm{a}$ & $13.1 \mathrm{a}$ & $11.1 \mathrm{a}$ & $8.10 \mathrm{a}$ \\
\hline Factor & df & \multicolumn{6}{|c|}{$P>\mathrm{F}$} \\
\hline Production system (PS) & 1 & $<0.0001$ & 0.0015 & 0.0288 & 0.0864 & $<0.0001$ & 0.0118 \\
\hline Fertility treatment (FT) & 3 & 0.0128 & 0.0593 & 0.1492 & 0.0321 & 0.0695 & 0.3269 \\
\hline $\mathrm{PS} \times \mathrm{FT}$ & 3 & 0.0486 & 0.0144 & 0.3214 & 0.0003 & 0.4108 & 0.1293 \\
\hline
\end{tabular}

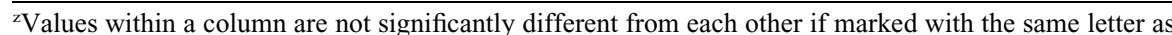
determined by Tukey's honestly significant difference test $(P \leq 0.05)$.

$\mathrm{N}=$ nitrogen.

Table 4. Mean soil (0- to 30-cm depth) microbial activity (FDA) and active carbon (POXC) from four fertility treatments in high tunnel and open field systems over three growing seasons (2011-13).

\begin{tabular}{|c|c|c|c|c|c|c|c|}
\hline \multirow[b]{3}{*}{ Treatment } & & \multicolumn{3}{|c|}{ FDA } & \multicolumn{3}{|c|}{ POXC } \\
\hline & & \multicolumn{3}{|c|}{$(\mu \mathrm{g}$ FDA/g soil/h) } & \multicolumn{3}{|c|}{ (mg POXC/kg soil) } \\
\hline & & 2011 & 2012 & 2013 & 2011 & 2012 & 2013 \\
\hline \multicolumn{8}{|l|}{ Production system } \\
\hline High tunnel & & $46.1 \mathrm{a}^{\mathrm{z}}$ & $47.1 \mathrm{a}$ & $50.1 \mathrm{a}$ & $507.0 \mathrm{a}$ & $504.2 \mathrm{a}$ & $502.8 \mathrm{a}$ \\
\hline Open field & & $49.1 \mathrm{a}$ & $51.4 \mathrm{a}$ & $39.6 \mathrm{~b}$ & $477.3 \mathrm{~b}$ & $540.3 \mathrm{a}$ & $543.3 \mathrm{a}$ \\
\hline \multicolumn{8}{|l|}{ Fertility treatment } \\
\hline Control & & $47.4 \mathrm{a}$ & $46.1 \mathrm{a}$ & $30.1 \mathrm{~b}$ & $464.8 \mathrm{~b}$ & $462.7 \mathrm{~b}$ & $446.0 \mathrm{c}$ \\
\hline Urea & & $47.9 \mathrm{a}$ & $49.8 \mathrm{a}$ & $34.4 \mathrm{~b}$ & $478.4 \mathrm{ab}$ & $479.4 \mathrm{~b}$ & $472.9 \mathrm{bc}$ \\
\hline Chicken manure & & $45.6 \mathrm{a}$ & $48.4 \mathrm{a}$ & $57.9 \mathrm{a}$ & $517.5 \mathrm{a}$ & $551.2 \mathrm{a}$ & $553.9 \mathrm{ab}$ \\
\hline Green manure & & $49.5 \mathrm{a}$ & $52.8 \mathrm{a}$ & $56.9 \mathrm{a}$ & $507.9 \mathrm{ab}$ & $595.6 \mathrm{a}$ & $619.4 \mathrm{a}$ \\
\hline Factor & df & \multicolumn{6}{|c|}{$P>\mathrm{F}$} \\
\hline Production system (PS) & 1 & 0.1945 & 0.1363 & 0.0026 & 0.0288 & 0.0564 & 0.0660 \\
\hline Fertility treatment (FT) & 3 & 0.6729 & 0.5094 & $<0.0001$ & 0.0245 & $<0.0001$ & $<0.0001$ \\
\hline $\mathrm{PS} \times \mathrm{FT}$ & 3 & 0.9146 & 0.0554 & 0.1148 & 0.0541 & 0.1582 & 0.0170 \\
\hline
\end{tabular}

${ }^{\mathrm{z}}$ Values within a column are not significantly different from each other if marked with the same letter as determined by Tukey's honestly significant difference test $(P \leq 0.05)$.
Soil $\mathrm{pH}$ was unaffected by production system after 3 years of vegetable production; however, fertility treatments did have a significant impact on soil $\mathrm{pH}$. Application of urea resulted in lower $\mathrm{pH}$ compared with animal manure and green manure treatments, and the animal manure had a greater $\mathrm{pH}$ than the control (Table 5). Furthermore, EC was greater in the high tunnel compared with the open field, and repeated application of animal manure and green manure inputs resulted in higher EC values compared with the control but were not different from urea (Table 5).

Total soil nutrients. Soil P was significantly impacted by both production system and fertility treatment. The high tunnel contained more available $\mathrm{P}$ (Bray-1 P) and potentially available $\mathrm{P}$ (Bray-2 $\mathrm{P}$ ) than the open field (Table 5). Bray-1 P, which represents $P$ readily available to plants, was greater in urea and animal manure treatments compared with green manure and control treatments. A significant production system $\times$ fertility treatment interaction was observed in Bray-1 P and was mainly driven by differences in available $\mathrm{P}$ in the urea treatment between the high tunnel and open field (HT, $58.3 \mathrm{ppm}$; OF, $32.8 \mathrm{ppm}$; $P=0.0002$ ). Bray-2 $\mathrm{P}$ was greater in both the animal manure and green manure treatments than urea and control treatments, whereas urea was greater than the control (Table 5). Soil K was unaffected by production system; however, levels of $\mathrm{K}$ were greater in the green manure treatment compared with urea and control treatments (Table 5). Similarly, percent base saturation of $\mathrm{K}$ was greater in the green manure treatment than urea and control treatments (Table 5). Soil Mg, Ca, cation exchange capacity, percent $\mathrm{Mg}$, percent $\mathrm{Ca}$, and total organic matter did not differ between production system or fertility treatment (data not shown).

\section{Discussion}

The impact of high tunnel vs. open field production on the yield of many economically important vegetable crops has been well studied. Although some investigations report increased vegetable yields in high tunnels (O'Connell et al., 2012; Waterer, 2003), others have reported similar or reduced levels of productivity (Rogers and Wszelaki, 2012; Wallace et al., 2012). In this study, we confirm that high tunnel production can increase vegetable crop productivity compared with open field production systems at the same location, but plant type plays a major role. In 2011, chard yield was lower in the high tunnel compared with the open field. Chard is a cool-season crop, and the lower productivity observed in the high tunnel may have resulted from greater temperatures, although we produced a heat-tolerant variety. Alternatively, lower chard productivity in the high tunnel may have resulted from the lower mineral $\mathrm{N}$ observed in the high tunnel compared with the open field in 2011. Sweet pepper marketable fruit yield and the number of all fruit grades were greater in the high 


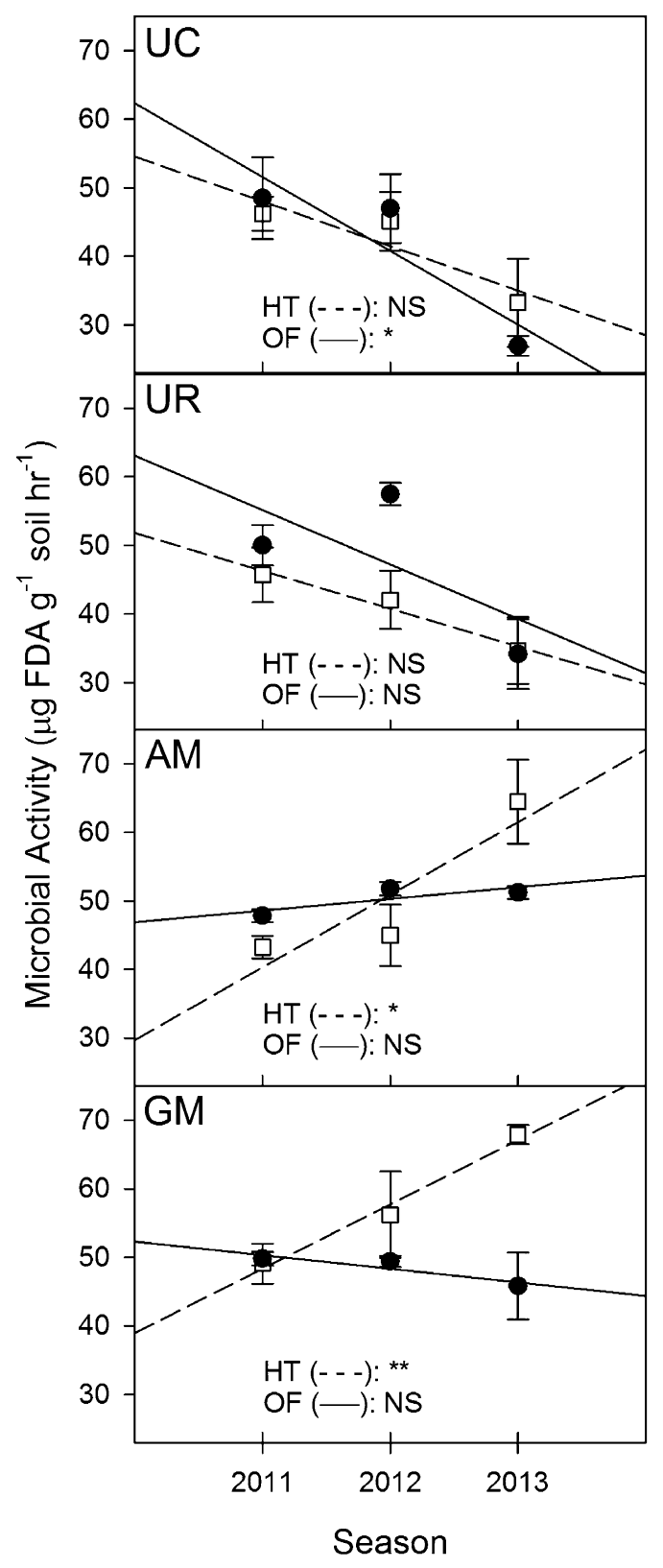

Fig. 1. Mean soil (0 to $30 \mathrm{~cm}$ depth) microbial activity as estimated by the hydrolysis of fluorescein diacetate (FDA hydrolysis) and regression lines from four fertility treatments $(\mathrm{UC}=$ unamended control; UR = urea; AM = animal manure; GM = green manure) in high tunnel ( $\square$; dashed lines; HT) and open field (-; solid lines; OF) systems over three growing seasons (2011-13). Error bars represent SE. NS, *, and ** indicate nonsignificant, significant at $P<0.05$, and $P<0.01$, respectively, for regression.

tunnel in both 2012 and 2013. The fact that sweet peppers were planted $20 \mathrm{~d}$ earlier in the high tunnel in 2012 likely improved yield compared with the open field during this season. However, even when planting date was only $2 \mathrm{~d}$ earlier in the high tunnel in 2013, significantly greater pepper yield was still observed inside the tunnel. These results indicate that vegetable growers need to carefully consider the choice of crop plants for use in high tunnel systems during main season production.

Meeting crop nutrient needs in high tunnels can be challenging, especially when using organic fertility amendments, as a result of higher nutrient requirements expected as a result of greater crop productivity in these systems. For example, in this study, we suspect that the green manure did not mineralize fast enough to meet the early-season crop nutrient needs for chard in 2011, as evidenced by the lower yield in these plots relative to the urea treatment. However, by midseason, soil mineral $\mathrm{N}$ was not different from the animal manure and urea treatments, indicating that the green manure could effectively supply $\mathrm{N}$ needs at this time. In 2012 and 2013, there were no differences in pepper yield among green manure, animal manure, and urea treatments when green manure rates were increased and included a hairy vetch cover crop along with the dehydrated alfalfa meal, demonstrating that green manure amendments can meet crop fertility needs. Yields in the animal manure treatments did not differ from urea in any growing season, confirming that these amendments mineralize rapidly and can be used to effectively meet fertility needs. These results are in accordance with other studies that have reported similar yields from animal manure and inorganic fertility amendments in high tunnel (Reeve and Drost, 2012) and open field (Brown et al., 1994; Drinkwater et al., 1998) systems.

Fertility management using organic amendments during vegetable production has been shown to promote greater soil quality compared with conventional practices (Drinkwater et al., 1995). Our results confirm that organic fertility amendments have the potential to improve soil quality in high tunnel as well as open field production systems, whereas intensive production with inorganic fertility amendments may reduce soil quality over time. After 3 years of intensive vegetable production, plots amended with animal manure and green manure had greater soil microbial activity than the urea and control plots in both production systems. This corresponds with previous studies that have demonstrated that soil incorporation of plant and animal byproducts can enhance soil biological activity compared with inorganic fertilizers in exposed agricultural settings (Bandick and Dick, 1999; Drinkwater et al., 1995; Mader et al., 2002). These results are important for vegetable growers to consider, because soil microbial activity directly contributes to crop productivity and has potential to help make crop systems more resistant to biotic and abiotic stress. For example, greater microbial activity as measured by FDA hydrolysis has been correlated with potential $\mathrm{N}$ mineralization (Drinkwater et al., 1995) and suppression of pathogens in pepper and tomato production (Boehm et al., 1997; Kim et al., 1997a, 1997b). Whereas disease was not observed in this study, our results indicate that fertility management does directly influence soil microbial activity, and these changes could potentially influence crop productivity in the presence of pathogens or other plant stress factors. Greater microbial activity in the high tunnel relative to the open field in 2013 also likely contributed to the greater end-of-season mineral $\mathrm{N}$ observed in the high tunnel system, which could help growers maintain crop productivity into the extended fall growing season.

Active soil C, characterized using a POXC assay, has been shown to be a sensitive indicator of changes in soil $\mathrm{C}$ in response to agricultural management (Culman et al., 2012; Weil et al., 2003), and previous studies have shown that cover crop incorporation and application of animal manures increase POXC relative to inorganic fertility inputs (Culman et al., 2013). Similarly, we found that the application of animal manure and green manure fertility amendments resulted in higher levels of active soil $\mathrm{C}$ after repeated amendment application. Although use of 


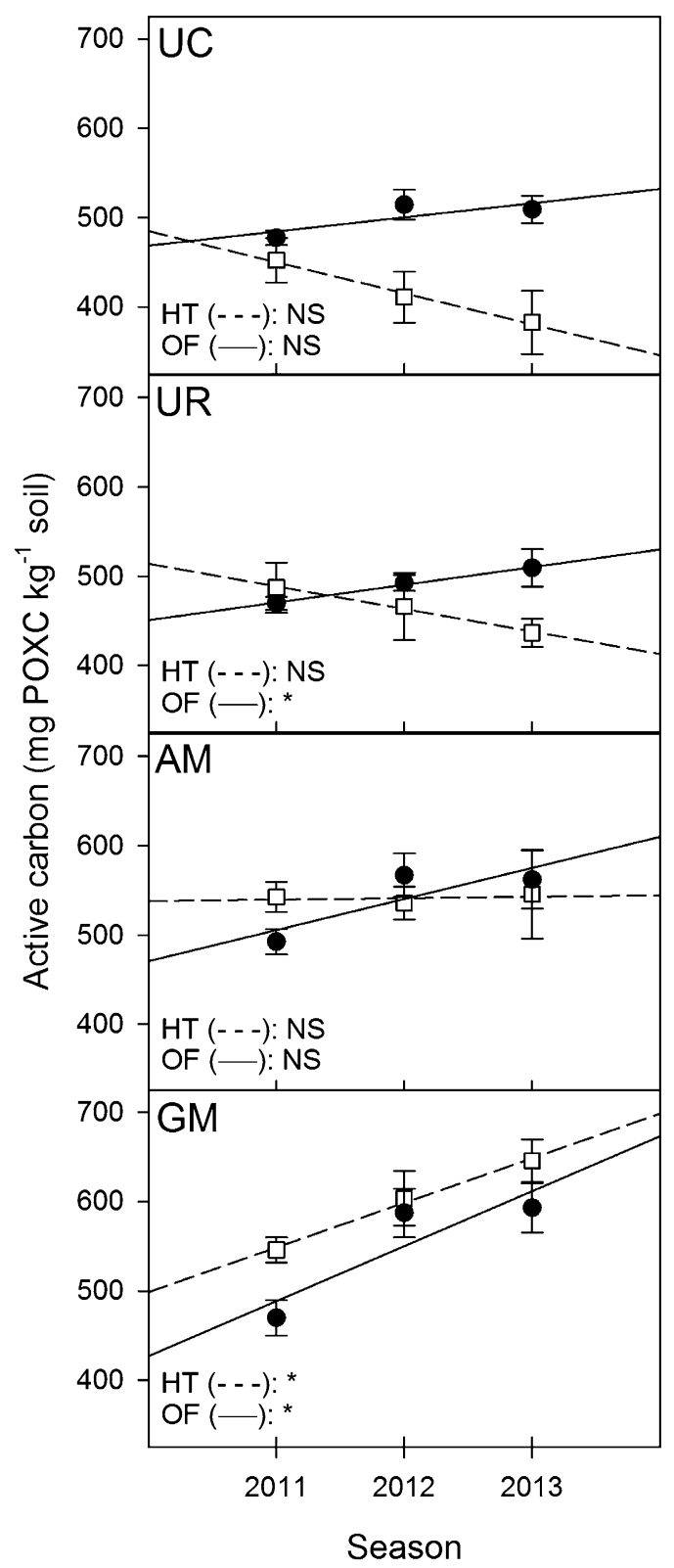

Fig. 2. Mean soil (0- to $30-\mathrm{cm}$ depth) active carbon as measured by permanganate oxidizable carbon (POXC) and regression lines from four fertility treatments $(\mathrm{UC}=$ unamended control; $\mathrm{UR}=$ urea; $\mathrm{AM}=$ animal manure; GM = green manure) in high tunnel ( $\square$; dashed lines; HT) and open field (0; solid lines; OF) systems over three growing seasons (2011-13). Error bars represent SE. Ns, *, and ** indicate nonsignificant, significant at the $P<0.05$, and $P<0.01$, respectively, for regression.

animal manure increased POXC relative to the control in each year of this trial, the green manure was the only treatment successful in accruing active $\mathrm{C}$ over time in both high tunnel and open field production systems. Because high tunnel structures increase soil temperatures (Wien, 2009), soil in these systems are likely more prone to $\mathrm{C}$ loss through increased microbial respiration. These findings are important for vegetable growers, particularly those using organic sources of fertility. Labile soil C pools contribute to soil tilth and provide energy for the mineralization of organic matter needed to supply beneficial microorganisms with adequate nutrients and energy. Evidence also suggests that $\mathrm{N}$ mineralization is positively correlated with levels of active C (Sano et al., 2006), which is essential to making nutrients available for plant uptake with organic amendments. On the other hand, repeatedly applying inorganic fertilizers could lead to an imbalance in soil nutrient cycling, increasing dependence on these sources to meet desired levels of crop production (Drinkwater and Snapp, 2007). However, although we show that using fall-planted cover crops as green manures can increase active $\mathrm{C}$ in high tunnel systems, the time necessary to establish a substantial cover crop might interfere with early planting of vegetable crops. Alternatively, growers could obtain the soil quality benefits of cover crops in high tunnels by planting them in the middle of summer, when the greater heat experienced in high tunnels is excessive for some vegetable crops.
Soil $\mathrm{pH}$ is a major driver of practically all chemical and biological properties in soil. Fluctuations in soil $\mathrm{pH}$ can alter the availability of macro- and micronutrients and can also affect the composition and function of soil microbial communities. In the absence of rainfall leaching events in high tunnels, there is potential for irrigation water to raise soil $\mathrm{pH}$ in areas like the Midwest where groundwater can be alkaline. In our study, soil $\mathrm{pH}$ was unaffected by production system, but we did observe impacts from the fertility treatments. After 3 years of intensive vegetable production, soil $\mathrm{pH}$ in the urea treatment was lower than treatments receiving animal manure or green manure inputs. Reduced soil $\mathrm{pH}$ as a result of inorganic fertilization has long been understood (Fox and Hoffman, 1981). Although fertilization with urea shifted the $\mathrm{pH}$ to a level more optimal for chard and sweet pepper in this study ( $\mathrm{pH} 6.0$ to 7.0 ), prolonged use could require additional inputs to balance $\mathrm{pH}$ to maintain nutrient availability and tolerable conditions for plant growth. For example, in the Midwest, frequent applications of lime are often needed to maintain soil $\mathrm{pH}$ at optimal levels for crop growth. Our results indicate that green manure amendments have the potential to maintain soil $\mathrm{pH}$ and reduce costs associated with $\mathrm{pH}$ modification in both high tunnel and open field production systems.

One major drawback of high tunnels, especially when using organic fertility sources, is the potential for soluble salt accumulation. In our trial, the high tunnel system had a greater EC compared with the open field after just 3 years of repeated fertility application. Elevated levels of EC in the high tunnel are likely a result of reduced leaching and increased rates of soil water evapotranspiration as a result of higher temperatures observed in these systems. Although our observed EC measurements were considered "nonsaline" and not in the range considered inhibitory to plants such as bell pepper ( 0.41 to $\left.0.8 \mathrm{dS} \cdot \mathrm{m}^{-1}\right)$ or chard $(1.21$ to 1.6 $\mathrm{dS} \cdot \mathrm{m}^{-1}$ ) (Dellavalle, 1992), prolonged cultivation in these structures without remedial measures could lead to excessive salt buildup (Knewtson et al., 2010b). Both animal manure and green manure treatments had greater EC relative to the control but were not different from treatments receiving urea. Increased soil salinity has previously been attributed to the use of animal-based manures (Edmeades, 2003), particularly poultry manure (Azeez and Van Averbeke, 2012), and frequent application could potentially result in problems for vegetable growers in high tunnels. Increased levels of EC in the green manure treatment in our study were likely a result of additional amendments used to supplement $\mathrm{P}$ and, in particular, $\mathrm{K}$ because we observed the greatest levels of available $\mathrm{K}$ in this treatment, and these amendments should be carefully balanced in high tunnel systems. In the case that salt levels become problematic for vegetable production, using moveable tunnels would allow growers to cycle 
Table 5. Mean soil (0- to 30-cm depth) pH, electrical conductivity (EC), available phosphorus (Bray-1 P), potentially available phosphorus (Bray-2 P), available potassium $(\mathrm{K})$, and percent base saturation potassium $\left(\% \mathrm{~K}_{\mathrm{sat}}\right)$ in 2013 from four fertility treatments in high tunnel and open field systems after 3 years of repeated fertility application.

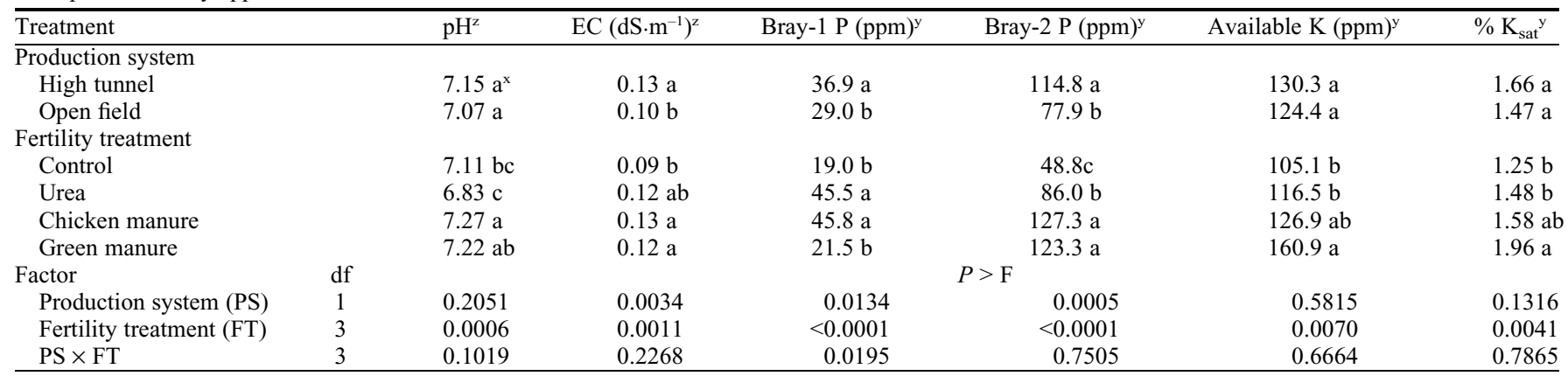

${ }^{\mathrm{z}}$ Data obtained from soil collected in 2013 during the midseason.

${ }^{\text {y }}$ Data obtained from soil collected in 2013 at the end of experimental trial determined by Midwest Laboratories (Omaha, NE).

${ }^{x}$ Values within a column are not significantly different from each other if marked with the same letter as determined by Tukey's honestly significant difference test $(P \leq 0.05)$.

between cultivated and fallow soil, possibly helping reduce buildup of soluble salts.

Another possible drawback of high tunnel systems is the potential to accumulate excessive levels of nutrients, which can negatively impact crops and lead to water quality problems. In our trial, available soil P (Bray-1 P) was greater in the high tunnel in comparison with the open field and was greater in urea and animal manure treatments, indicating the potential for $\mathrm{P}$ loading when applying either inorganic or animal-based manure fertilizers in high tunnel systems. Our findings are consistent with other studies that have shown excessive $\mathrm{P}$ in soil receiving poultry litter amendments (Mikkelsen, 2000; Reeve and Drost, 2012), and the potential consequences of high P loading are well explained by Rosen and Allan (2007). In contrast, the available soil $\mathrm{P}$ in green manure treatment was not different from the control, and our data suggest that much of the $\mathrm{P}$ supplemented remained in an active reserve pool (Bray-2 P). This indicates that mineralization of organic $\mathrm{P}$ sources could be problematic in high tunnel systems where soil moisture saturation is more limited than open field systems as a result of limited exposure to rainfall. High tunnel growers should perform routine soil nutrient analyses to monitor $P$ levels, to meet crop nutrient needs, and limit negative environmental or human health impacts associated with $\mathrm{P}$ accumulation. Application of animal-based manures should be limited to meeting crop P needs to limit P loading (Eghball and Power, 1999). Although expensive, a variety of soluble sources of fertility amendments like bloodmeal, which have high $\mathrm{N}$ relative to $\mathrm{P}$, could be used to manage $\mathrm{N}$ fertility and limit $\mathrm{P}$ buildup when relying on organic amendments.

High tunnels offer the luxury of season extension in temperate climates by allowing environmental control during early spring and late fall leading to the potential for greater yield and produce quality. This study demonstrates that high tunnels can support enhanced productivity of sweet peppers compared with open field production systems in the midwest United States. Furthermore, we show using chicken litter or a legume cover crop as a green manure results in comparable sweet pepper yields and improved soil quality compared with a chemical fertilization regime in both high tunnel and open field systems. Managing fertility using animal manures or green manures could also aid in establishing nutrient pools with longer mean residence time, recoupling nutrient cycling, and improving the resiliency of intensively cropped vegetable production systems (Drinkwater and Snapp, 2007). However, additional long-term research is needed to confirm that these amendments can be managed without salt and $\mathrm{P}$ buildup, which can reduce plant productivity and result in potential negative environmental and human health impacts. Further investigations assessing integrated fertility management practices and the use of several cover crops or mixes on high tunnel productivity and soil quality would also be valuable. In addition, research investigating additional methods of fertility management in high tunnel systems such as fertigation with soluble sources of nutrients to supplement soil amendments at critical crop uptake periods could lead to more targeted management and even greater crop productivity in vegetable cropping systems.

\section{Literature Cited}

Araki, H., S. Hane, Y. Hoshino, and T. Hirata. 2009. Cover crop use in tomato production in plastic high tunnel. Hort. Environ. Biotechnol. 50:324-328

Azeez, J.O. and W. Van Averbeke. 2012. Dynamics of soil $\mathrm{pH}$ and electrical conductivity with the application of three animal manures. Commun. Soil Sci. Plant Anal. 43:865-874.

Bandick, A.K. and R.P. Dick. 1999. Field management effects on soil enzyme activities. Soil Biol. Biochem. 31:1471-1479.

Bary, A.I., C.G. Cogger, and D.M. Sullivan. 2000. Fertilizing with manure. Pacific Northwest Ext. Publ. 533. Washington State Univ. Coop. Ext., Pullman, WA.

Boehm, M.J., T.Y. Wu, A.G. Stone, B. Kraakman, D.A. Iannotti, G.E. Wilson, L.V. Madden, and H.A.J. Hoitink. 1997. Cross-polarized magicangle spinning $\mathrm{C}-13$ nuclear magnetic resonance spectroscopic characterization of soil organic matter relative to culturable bacterial species composition and sustained biological control of Pythium root rot. Appl. Environ. Microbiol. 63:162-168.

Brown, J.E., J.M. Dangler, C.H. Gilliam, D.W. Porch, and R.L. Shumack. 1994. Comparison of broiler litter and inorganic nitrogen, phosphorus, and potassium for double-cropped sweet corn and broccoli. J. Plant Nutr. 17:859-867.

Brown, J.R.(ed.). 1998. Recommended chemical soil test procedures for the north central region. NCR Res. Pub. 221. Missouri Agr. Expt. Sta., Columbia, MO.

Culman, S.W., S.S. Snapp, M.A. Freeman, M.E. Schipanski, J. Beniston, R. Lal, L.E. Drinkwater, A.J. Franzluebbers, J.D. Glover, A.S. Grandy, J. Lee, J. Six, J.E. Maul, S.B. Mirsky, J.T. Spargo, and W.M. Wander. 2012. Permanganate oxidizable carbon reflects a processed soil fraction that is sensitive to management. Soil Sci. Soc. Amer. J. 76:494-504.

Culman, S.W., S.S. Snapp, J.M. Green, and L.E. Gentry. 2013. Short- and long-term labile soil carbon and nitrogen dynamics reflect management and predict corn agronomic performance. Agron. J. 105:493-502.

Dellavalle, N.B.(ed.). 1992. Determination of specific conductance in supernatant 1:2 soil:water solution, p. 44-50. In: Handbook on reference methods for soil analysis. Soil and Plant Analysis Council, Inc., Athens, GA.

Drinkwater, L.E., D.K. Letourneau, F. Workneh, A.H.C. Van Bruggen, and C. Shennan. 1995. Fundamental differences between conventional and organic tomato agroecosystems in California. Ecol. Appl. 5:1098-1112.

Drinkwater, L.E. and S.S. Snapp. 2007. Nutrients in agroecosystems: Rethinking the management paradigm. Adv. Agron. 92:163-186.

Drinkwater, L.E., P. Wagoner, and M. Sarrantonio. 1998. Legume-based cropping systems have reduced carbon and nitrogen losses. Nature 396:262-265.

Edmeades, D.C. 2003. The long-term effects of manures and fertilisers on soil productivity and quality: A review. Nutr. Cycl. Agroecosyst. 66:165-180.

Eghball, B. and J.F. Power. 1999. Phosphorus- and nitrogen-based manure and compost applications: Corn production and soil phosphorus. Soil Sci. Soc. Amer. J. 63:895-901.

Fox, R.H. and L.D. Hoffman. 1981. The effect of $\mathrm{N}$-fertilizer source on grain-yield, $\mathrm{N}$-uptake, soil-pH, and lime requirement in no-till corn. Agron. J. 73:891-895. 
Green, V.S., D.E. Stott, and M. Diack. 2006. Assay for fluorescein diacetate hydrolytic activity: Optimization for soil samples. Soil Biol. Biochem. 38:693-701.

Kalra, Y.P. 1995. Determination of $\mathrm{pH}$ of soils by different methods: Collaborative study. J. AOAC Intl. 78:310-324.

Kim, K.D., S. Nemec, and G. Musson. 1997a. Control of Phytophthora root and crown rot of bell pepper with composts and soil amendments in the greenhouse. Appl. Soil Ecol. 5:169-179.

Kim, K.D., S. Nemec, and G. Musson. 1997b. Effects of composts and soil amendments on soil microflora and Phytophthora root and crown rot of bell pepper. Crop Prot. 16:165-172.

Knewtson, S.J.B., E.E. Carey, and M.B. Kirkham. 2010a. Management practices of growers using high tunnels in the central great plains of the United States. HortTechnology 20:639-645.

Knewtson, S.J.B., R. Janke, M.B. Kirkham, K.A Williams, and E.E. Carey. 2010b. Trends in soil quality under high tunnels. HortScience 45:1534 1538.

Komatsuzaki, M. and H. Ohta. 2007. Soil management practices for sustainable agro-ecosystems. Sustain. Sci. 2:103-120.

Lamont, W.J. 2009. Overview of the use of high tunnels worldwide. Hort Technology 19:25-29.

Maas, E.V. and G.J. Hoffman. 1977. Crop salt tolerance-Current assessment. J. Irrig. Drain. Div. 103:115-134.

Mader, P., A. Fliessbach, D. Dubois, L. Gunst, P. Fried, and U. Niggli. 2002. Soil fertility and biodiversity in organic farming. Science 296:1694-1697.
Maynard, D.N. and G.J. Hochmuth. 1997. Knott's handbook for vegetable growers. 4th Ed. Wiley, New York, NY.

Mikkelsen, R.L. 2000. Beneficial use of swine-byproducts: Opportunities for the future, p. 451480. In: Power, J.F. and W.A. Dick (eds.). Land application of agricultural, industrial and municipal by-products. Soil Sci. Soc. Am., Madison, WI.

O’Connell, S., C. Rivard, M.M. Peet, C. Harlow, and F. Louws. 2012. High tunnel and field production of organic heirloom tomatoes: Yield, fruit quality, disease, and microclimate. HortScience 47:1283-1290.

Pottorff, L.P. and K.L. Panter. 2009. Integrated pest management and biological control in high tunnel production. HortTechnology 19:61-65.

Reeve, J. and D. Drost. 2012. Yields and soil quality under transitional organic high tunnel tomatoes. HortScience 47:38-44.

Rogers, M.A. and A.L. Wszelaki. 2012. Influence of high tunnel production and planting date on yield, growth, and early blight development on organically grown heirloom and hybrid tomato. HortTechnology 22:452-462.

Rosen, C.J. and D.L. Allan. 2007. Exploring the benefits of organic nutrient sources for crop production and quality: A review. HortTechnology 17:422-430.

Sano, S., J. Yanai, and T. Kosaki. 2006. Relationships between labile organic matter and nitrogen mineralization in Japanese agricultural soils with reference to land use and soil type. Soil Sci. Plant Nutr. 52:49-60.

Sarrantonio, M. 1994. Northeast cover crop handbook. Rodale Institute, Kutztown, PA.
Snapp, S.S., S.M. Swinton, R. Labarta, D. Mutch, J.R. Black, R. Leep, J. Nyiraneza, and K. O'Neil. 2005. Evaluating cover crops for benefits, costs and performance within cropping system niches. Agron. J. 97:322-332.

Timmons, D. and Q.B. Wang. 2010. Direct food sales in the United States: Evidence from state and county-level data. J. Sustain. Agr. 34:229-240.

USDA. 2005. United States standards for grades of sweet peppers. USDA-AMS. 5 Mar. 2012. $<$ http://www.ams.usda.gov/AMSv1.0/getfile? dDocName $=$ STELPRDC5050318 $>$.

USDA. 2014. Soil health. USDA-NRCS. 11 Feb. 2014. <http://www.nrcs.usda.gov/wps/portal/ $\mathrm{nrcs} / \mathrm{main} / \mathrm{soils} /$ health/>.

Wallace, R.W., A.L. Wszelaki, C.A. Mils, J.S. Cowan, J. Martin, J. Roozen, B. Gundersen, and D.A. Inglis. 2012. Lettuce yield and quality when grown in high tunnel and open-field production systems under three diverse climates. HortTechnology 22:659-668.

Waterer, D. 2003. Yields and economics of high tunnels for production of warm-season vegetable crops. HortTechnology 13:339-343.

Weil, R.R., K.R. Islam, M.A. Stine, J.B. Gruver, and S.E. Samson-Liebig. 2003. Estimating active carbon for soil quality assessment: A simplified method for laboratory and field use. Amer. J. Altern. Agr. 18:3-17.

Wien, H.C. 2009. Microenvironmental variations with the high tunnel. HortScience 44:235-238.

Yao, L.X., G.L. Li, S.H. Tu, S. Gavin, and Z.H. He 2007. Salinity of animal manure and potential risk of secondary soil salinization through successive manure application. Sci. Total Environ. 383:106-114. 